\title{
Borsa İstanbul'a Kayıtlı Turizm Şirketlerinin 2011-2015 Dönemi Finansal Performanslarının TOPSİS ile Analizi
}

\author{
Mahmut ERDOĞAN*, Adilya YAMALTDINOVA ${ }^{* *}$ \\ ÖZ
}

Bu çalışmada, Borsa İstanbul'da (BIST) kote olmuş 13 turizm şirketinin 2011-2015 dönemine ait finansal performansları TOPSIS yöntemi ile incelenmiştir. Çalışmada, şirketlerin finansal güçlülügünü tespit etmek amacıyla öncelikle mali oranlar hesaplanmış, finansal oranlar kullanılarak TOPSIS metoduyla genel şirket performansı tespit edilmiş ve şirketler bu skorlara göre sıralanmıştır. Her bir şirketin dönemler itibariyle sahip olduğu performans sıralaması yapıldıktan sonra, dönemlik ortalamalar üzerinden şirketlerin performans sıralaması gerçekleştirilmiştir. Çalışmanın bulguları, turizm sektöründe faaliyet gösteren şirketlerin finansal performans puanlarının yıllara göre değiştiğini göstermektedir. Analiz sonuçlarına göre 2011 yılında en iyi performansa sahip turizm şirketleri sırasıyla Net Turizm, Tekart Turizm ve Marmaris Altınyunus iken en kötü performansa sahip şirket ise Metemtur'dur. Ancak 2015 yılında ise Metemtur, Kuşadası Turizm ve Marmaris Altınyunus en iyi performans sergilerken, Martı Otel en kötü performansa sahip bulunmuştur. İncelenen dönemde Net Turizm ve Marmaris Altınyunus sürekli iyi performans gösterirken, Metemtur ise en fazla dalgalanma gösteren şirket olmuştur.

Anahtar Kelimeler: Turizm, BIST, Finansal Performans, TOPSİS.

JEL Sinıflandırması: G15, G17, G32

\section{Financial Performance Analysis of BIST Tourism Companies with TOPSIS for 2011-2015 Period}

\begin{abstract}
The main aim of this paper is to investigate of financial performance of 13 tourism firms quoted on BIST with TOPSIS method by exploitation of financial ratios for the 2011-2015 period. Basically, to determine financial power of the tourism firms financial ratios have measured and then general corporate performance scores estimated by TOPSIS method. Algorithm of the TOPSIS method is repeated and ranking orders of firms are calculated for each year. However, companies' yearly performances are outlined and an average ranking is stated for 6 years. Lastly, tourism corporations have ranked with these scores. The result of this paper shows that financial performance of tourism companies point instability out during the all period. According to the results of analysis Net Turizm, Tekart Turizm, and Marmaris Altinyunus have the best performance in 2011 respectively, but Metemtur has the worst. On the other hand, surprisingly, Metemtur has the best financial efficiency and Mart1 Otel has the worst performance in 2015. However, Net Turizm and Marmaris Altinyunus have been continuing their financial stability and Metemtur is very volatile company in given term.
\end{abstract}

Keywords: Tourism, BIST, Financial Performance, TOPSIS.

JEL Classification: G15, G17, G32

Geliş Tarihi / Received: 22.08.2017 Kabul Tarihi / Accepted: 26.11.2017

\footnotetext{
Yrd. Doç. Dr., Kırgızistan Türkiye Manas Üniversitesi, İÏBF, Finans ve Bankacılık Bölümü, mahmut.erdogan@manas.edu.kg, https://orcid.org/0000-0002-7085-3995

**Arş. Gör., Kırgızistan Türkiye Manas Üniversitesi, İİBF, İşletme Bölümü, adilya.yamaltdinova@ @manas.edu.kg, https://orcid.org/0000-0003-1426-5993
} 


\section{GİRIŞ}

Dünya Seyahat ve Turizm Konseyi, seyahat ve turizmin dünyanın en büyük endüstrilerinden biri olmayı sürdürdüğünü ve sektörün 2015 yılında dünya GSMH'nın \%9,8'ini ürettiğini ve parasal olarak 7,2 trilyon dolar değere ulaşan etkileyici güce sahip olduğunu belirtmiştir. Buna ek olarak turizm sektörü, 284 milyon insana istihdam olanağ sağlamıştır (WTTC, 2017). 2022 yılına kadar 328 milyon kişinin turizm sektöründe istihdam edileceği ve yeryüzündeki her 10 kişiden birinin bu sektörde çalışacağ 1 beklenmektedir (Chou, 2013: 226). Milli gelir içerisinde yer alan turizm gelirleri, çoğaltan etkisiyle ekonomiye olumlu katk1 sağlayıp, birçok sektörü de desteklemektedir (Çetintaş \& Bektaş, 2008: 37). Bununla birlikte, döviz girdisi yoluyla dış açıkların giderilmesi ve ödemeler bilançosunun iyileştirilmesine katkı sağlama yoluyla da ekonomiye olumlu etki etmektedir (Yavuz, 2006:162).

Dünya genelinde olduğu gibi turizm, Türkiye'de de sürekli gelişim gösteren bir sektör olma özelliğine sahiptir. Turizm faaliyetlerinin başladığ 1 doksanlı yıllarda ülkemize gelen turist sayısı 5,3 milyon iken 2015 yılında yaklaşık olarak 42 milyon olarak gerçekleşmiştir (www.tursab.org.tr). Bu endüstride 2016 yılında yaşanan olumsuz politik gelişmelere rağmen Türkiye, turistlerin destinasyon olarak tercih ettikleri ülkeler kategorisinde dünya genelinde 6 . sırada yer almış ve ilerleyen yıllarda ilk beş ülke içerisine girmesi tahmin edilmektedir (TOBB Turizm Raporu, 2016:18). Türkiye'de turizm gelirlerinin GSMH içindeki payı 1963 yılında \% 0,1'den, 1995 yılında \% 2,9'a, 2005 yilında \% 4,2'ye ve 2015 yılında \% 6,2'ye yükselmiştir. Turizm gelirlerinin ihracata oranı ise aynı dönemde benzer şekilde eğilime sahip olup; 1963 yllında \%2,1 iken, 1995'te \% 22,9 ve 2015 yılında \%21,9 olarak gerçekleşmiştir (www.tursab.org.tr).

Ülkelerin turizmde rekabet seviyelerini belirlemek amaciyla Dünya Ekonomik Forumu tarafından yayınlanan Seyahat ve Turizm Rekabet Edebilirlik Raporu'na göre Türkiye 2009 yılı Seyahat ve Turizm Rekabet Endeksinde 56. sırada yer almıştır. 2011 yılında ise 50. Sıraya yükselmiş, 2013 yılında 46. sıraya ilerlemiş ve son olarak 2015 yılında 2 basamak daha yükselerek 44. sıraya ilerlemiştir (WEF, 2015: 5). Bu ilerlemelere rağmen Türkiye, turizm geliri yönünden İspanya, Fransa ve İtalya'nın oldukça gerisinde yer almaktadır. Bunun bir sebebi; uluslararası turizm pazarına görece yeni katılan Hırvatistan, Romanya ve Bulgaristan'ın düşük fiyat politikası uygulamaları, rekabetin sürdürülebilmesi amacıyla Türkiye'yi de bu politikaya zorlamasıdır (Gökdeniz \& Erdem, 2015: 14). Bu rekabetçi ortamda, turizm işletmelerinin varlığını sürdürme ve büyüyebilme olgusu, daha fazla önem taşımaktadır. Bilginin yatırımcılar arasında gelişen teknoloji yoluyla hızla yayılması ve ekonomik entegrasyonun artışı, işletmelerin sadece yerel değil uluslararası işletmelerle olan rekabetini de artırmışıı. Kendi faaliyet alanında verimliliği ve performansı yüksek işletmelerin varlığını sürdürmesi beklenmektedir. Turizm işletmelerinin sergileyeceği performans sadece kendilerini değil, sektör yatırımcıları ve ekonomi açısından da büyük önem taşımaktadır (Uygurtürk \& Korkmaz, 2012: 96).

Finansal performans ölçümü yoluyla turizm işletmelerinin finansal durumları, yatırım verimliliği ve risk dereceleri tespit edilebilir. Bununla birlikte finansal performans ölçümü, geçmişin değerlendirilmesi, gelecekteki yatırım ve finansman kararlarının verilmesi, stratejik hedeflerin gerçekleştirilmesi ve finansal yapı tercihi hakkında yöneticilere değerli bilgiler temin etmektedir (Uygurtürk \& Korkmaz, 2012: 96).

Bu çalışmanın amacı, Türkiye'de turizm sektöründe 2011-2015 döneminde faaliyet gösteren BIST'te kayıtlı işletmelerin finansal performanslarını TOPSIS yöntemiyle analiz etmektir. Çalışmada bu dönemde BIST'te kayıtlı 13 şirkete ait finansal oranlar kullanılmıştır. Bu yöntem kullanılarak otomotiv, ulaştırma, gıda, teknoloji ve gayrimenkul sektörlerinde faaliyet gösteren şirketlerin finansal performansları literatürde incelenmiştir. Son yıllarda artan rekabetin yanı sıra politik gelişmeler de turizm şirketlerinin performanslarını olağanüstü etkilemiştir. Bu sebeple, turizm sektöründe faaliyet gösteren şirketlerin özellikle kriz dönemlerindeki finansal 
performanslarının TOPSIS yöntemiyle incelenmesinin literatüre katkı sağlayacağı düşünülmüştür.

Çalışmanın izleyen bölümlerinde öncelikle bu alanda daha önce yapılan çalışmalar incelenmiştir. Ardından çalışmada kullanılan veri ve yöntem sunulmuştur. İzleyen bölümde TOPSIS yönteminin bulguları incelenmiştir. Çalışma sonuç ve tartışma bölümüyle son bulmaktadır.

\section{LITERATÜR}

Bir çok kriterli karar verme yöntemi olan TOPSIS (Technique for Order Preference by Similarity to Ideal Solutions - İdeal Çözüme Benzerlik Bakımından Sıralama Performansı Tekniği) ilk defa Hwang ve Yoon (1981) tarafindan geliştirilmiş olup (Uygurtürk \& Korkmaz, 2012: 97), alternatif seçeneklerin belirli kriterlere göre ve kriterlerin alabileceği en yüksek ve en düşük değerlerin ideal duruma göre karşılaştırılmasına olanak vermektedir (Saldanlı ve Sırma, 2014: 186). Farklı sektörler için TOPSIS yöntemi kullanılarak işletmelerin finansal performanslarını karşılaştırmalı olarak inceleyen çalışmalar mevcuttur. Turizm endüstrisinde faaliyet gösteren işletmelerin finansal performanslarını inceleyen Zhang vd. (2011); Huang \& Peng (2012), Ergül (2014), Özçelik \& Kandemir (2015), Morteza vd. (2016), elektrik üretim şirketlerinin performanslarını İlkuçar ve Çiftçi (2016); teknoloji şirketlerinin performanslarını Dumanoğlu \& Ergül (2010), Türkmen \& Çağıl (2012), Bulgurcu (2012) incelemişlerdir. Buna ek olarak, üretim işletmelerinin performansını Akbulut \& Rençber (2015), banka performansını inceleyen Demireli (2010), Yayar \& Baykara (2012) çalışmalarında bu yöntem kullanılmıştır.

Çin'de Yangtze Nehir Deltasının turizm rekabet edebilirliğini inceleyen Zhang vd. (2011); rekabet edebilirliği değerlendirmek için TOPSIS yöntemini uygulamışlardır. Bu deltada bulunan 16 şehrin karşılaştırıp değerlendirerek; değerlendirme sonuçlarının objektif ve uygun olduğunu, bu sonuçların da turizmin gelişmesi önündeki sorunların belirlenmesi ve bunlara çözüm üretilmesi bakımından turizm idaresine yardım edebileceğini ifade etmişlerdir.

Huang \& Peng (2012), Çin, Hong-Kong, Japonya, Güney Kore, Malezya, Singapur, Tayvan, Tayland ve Filipinleri kapsayan 9 Asya ülkesinin Turizm Bölgesi Rekabet gücünü analiz etmek için Bulanık Rasch TOPSIS yöntemini kullanmışlardır. Çalışmalarında 2009 yılı için 6 kriter ve 15 endeks yer almaktadır. Bulguları, Asya ülkeleri arasında rekabet edebilirlik düzeyinin en yüksekten en düşüğe doğru Çin, Japonya, Hong-Kong, Singapur, Malezya, Tayvan, Tayland, Güney Kore ve Filipinler şeklinde sıralandığını göstermektedir.

Türk turizm endüstrisinde faaliyet gösteren BIST'e kayıtll yedi şirketin 2005-2012 döneminde en yüksek finansal performansa sahip olanını belirlemede TOPSIS yönteminin karar vermede başarılı olup olmadığını test eden Ergül (2014), MAALT, NETTUR ve PKENT şirketlerinin başarılı olduklarını tespit etmiştir. Ayrıca, TOPSIS yönteminin en yüksek performanslı şirketin belirlenmesinde karar vermeyi kolaylaştıran etkin bir yöntem olduğu sonucuna ulaşmıștır. Benzer biçimde Türk turizm șirketlerinin finansal performanslarını likidite, kaldıraç, karlılık ve faaliyet oranları yardımıyla ölçmeyi amaçlayan Özçelik \& Kandemir (2015); BIST'te kote olmuş yedi işletmenin 2010-2014 dönemi için mali performanslarını değerlendirmiştir. 2014 yılında en iyi performans sergileyen işletmelerin sırasıyla MAALT, PKENT ve METUR olduğunu belirlemişlerdir. Finansal oranların TOPSIS yönteminde kullanılması yoluyla, turizm endüstrisindeki şirket performanslarının değerlendirilmesinde kullanılabileceğini ileri sürmüşlerdir.

Morteza vd. (2016), İran'da bulanık bir çevrede bütünleşik kıyı yönetim stratejilerine göre turizm sektöründeki yatırımcılara yardım etmek amacıyla çeşitli turizm alternatifleri arasında optimal turizm alanlarını belirleme amacıyla, turizm alanının yapısını seçme problemi 
için Analitik Hiyerarşi sürecini kullanmışlardır. Bulanık TOPSIS yöntemi ise son öncelikleri sağlamak için kullanılmıştır. Turizm alanı seçiminde, önerdikleri modelin karar verme süreçlerindeki etkinliği önemli düzeyde artırdığını belirtmişlerdir.

BIST’e kayıtlı 6 elektrik üretim işletmesinin 2015 yılı finansal performanslarını TOPSIS yöntemiyle inceleyen İlkuçar ve Çiftçi (2016); C+ yazılımı ile geliştirilen program yoluyla yaptıkları TOPSIS çözümlemesinde kar ve maliyetleri içeren 12 farklı kriter kullanmışlardır. Analiz sonucuna göre elektrik sektöründe AYEN şirketinin en iyi performansı gösterirken, AKENER şirketinin ise en kötü performansa sahip olduğunu tespit etmişlerdir.

Yükçü \& Atağan (2010) ise Türkiye'de faaliyet gösteren 3 adet otel işletmesinin aktif kârlılı̆̆1, artık kârı, ekonomik katma değer ve kârlılık oranları ile performans sıralaması elde edilmiştir. Çalışma sonucunda, TOPSIS yönteminin diğer çok kriterli karar verme yöntemleri gibi karar vericiye, farklı seçenekleri ortak paydada birleştirme yoluyla objektif değerlendirme yapma firsatı sunduğunu ifade etmişlerdir.

Dumanoğlu \& Ergül (2010) BIST'te işlem gören 11 teknoloji şirketinin finansal performansını TOPSIS yöntemiyle incelemişlerdir. Teknoloji şirketlerinin finansal performanslarının sektör ve firma temelinde en iyi şekilde değerlendirilmesinde TOPSIS yönteminin uygunluğunu ileri süren araştırmacılar çalışmalarında 2006-2009 dönemi verilerini kullanmışlardır. Benzer şekilde, BIST’e kayıtlı 12 bilişim işletmesinin 2007-2010 dönemi finansal performanslarını TOPSIS yöntemi ile sekiz finansal oran çerçevesinde inceleyen Türkmen \& Çağıl (2012); bu endüstride faaliyet gösteren PKART işletmesinin en iyi performansa sahip olduğunu, KAREL ve ARENA işletmelerinin de istikrarlı performans gösterdiklerini belirlemişlerdir. LOGO şirketinin ise yıllar itibariyle finansal performansının azaldığını tespit etmişlerdir. Bulgurcu (2012) da BIST'e kayıtlı 13 teknoloji şirketinin 20092011 dönemi mali tablolarından sağladığ 10 adet finansal oranı TOPSIS yöntemiyle analiz etmiştir. Çalışma bulguları, TOPSIS skorları ile şirket piyasa değeri arasında tutarlı bir ilişkinin olmadığını göstermiştir.

Demireli (2010) Türkiye'deki 3 adet kamu sermayeli bankanın 2001-2007 döneminde finansal performansını TOPSIS yöntemiyle incelemiştir. $\mathrm{Bu}$ yöntemde eşit biçimde ağırlıklandırılmış, on adet finansal oran kullanmıştır. Yıllar itibariyle banka skorlarının farklılık gösterdiğini belirleyen araştırmacı, kamu bankalarının yerel ve global finansal krizlerden olumsuz etkilendiğini, skorların sürekli dalgalanmalar gösterdiğini ileri sürmüştür. Türkiye'deki Katılım bankalarının performansını inceleyen Yayar \& Baykara (2012) etkinlik ve verimlilik bakımından ayırdıkları finansal performans göstergeleriyle 2005-2011 döneminde 4 bankayı TOPSIS yöntemiyle analiz etmişlerdir. Etkinlik göstergeleriyle iyi performansa sahip bir bankanın, verimlilik göstergelerinde iyi performansa sahip olmadığını gösteren çelişkili bulgular sunmuşlardır.

İşletmelerin finansal performansını çok kriterli karar verme yöntemlerinden TOPSIS dışında farklı yöntemlerle analiz eden çalı̧̧malar da vardır. Gri İlişkisel Analiz yöntemini kullanarak turizm şirketlerinin finansal performanslarını finansal oranlar yoluyla ölçmeyi amaçlayan Ecer \& Günay (2014) çalışmalarında 2008-2012 döneminde BIST'te işlem gören dokuz turizm şirketinin performanslarını likidite, kaldıraç, karlılık ve faaliyet göstergeleri bazında on yedi finansal orana göre incelemişlerdir. Çalışma bulgularına göre turizm şirketlerinin finansal performans ölçümüne göre en önemli gösterge kaldıraç olarak belirlenmiş ve bu şirketlerin borçlanma kararlarında daha dikkatli olmaları gerektiği iddia edilmiştir. Buna ek olarak sırasıyla karlılık, faaliyet ve likidite göstergelerinin önemli faktörler olduğu belirlenmiştir. Turizm şirket yöneticilerinin kar artırma yönünde karar vermeleri, varlıklarını verimli kullanmadıkları ve kısa vadeli borçlarını dönen varlıkları ile karşılamada başarılı olamadıklarını ifade etmişlerdir. 
Karadeniz v.d. (2017) ise BIST'te işlem gören 10 adet turizm şirketinin finansal performanslarını 2014 yılı için dikey analiz yöntemi ile incelemiş ve sektör ile karşılaştırmışlardır. Çalışmalarının sonucunda halka açık turizm şirketlerinin sektör geneline oranla daha yüksek seviyede maddi duran varlık bulundurduklarını belirlemişlerdir. Satışların maliyeti ve genel yönetim giderleri ise sektör ortalamaları ile benzer düzeyde olduğunu ifade etmiş̧lerdir. Karlılık açısından incelendiğinde ise bu şirketlerin satışlarında ziyade faaliyet dışı gelir ve giderlerinin dönem karını belirlemede önemli kalem olduğu ileri sürmüşlerdir. Çalışma bulguları Ayces, Ulas ve Utpya şirketlerinin incelenen dönemde zarar ettikleri ancak diğer şirketlerin ise sektöre oranla kar marjlarının daha yüksek olduğunu göstermektedir.

Aydeniz (2009) BIST’e kayıtlı gıda ve içecek şirketlerinin finansal performanslarına makroekonomik faktörlerin etkisini 1998-2007 döneminde 31 şirketin verisiyle incelemiştir. Doğrusal regresyon analizi kullandıkları çalışmalarında özkaynak karlılığ 1 , aktif karlılı̆̆ 1 ve satış karlılığını en fazla ÜFE ve TÜFE'nin etkilediğini, EBIT ve EBITDA'yı ise kapasite kullanım oranının etkilediğini belirtmiş ve NOPAT'1 ise faiz oranlarının etkilediğini bulmuşlardır. İşletmenin gelecekte tüfe artışıyla karlarının artacağını, kapasite kullanım oranı artışıyla EBIT ve EBITDA'nın da artacağını ileri sürmüştür. Buna ek olarak faiz oranları düşüşünün NOPAT'1 artıracağını iddia etmiştir.

Cheng (2011) Tayvan'da uluslararası alanda turizmde ortaya çıkan gelişmeler ve krizlerin otel performanslarına tepkisini ölçmek için panel regresyon kullandığ toplam gelen turist sayısındaki artı̧̧la temsil edilen uluslararası turizm gelişmesinin otel satış ve karlılı̆g 1 üzerinde doğrudan etkisi olduğunu belirlemiştir. İkinci olarak, uluslararası turizm gelişmeleri ve otel hisse senedi getirileri arasında güçlü bir bağ olmadığını bulmuştur. Üçüncü olarak, deprem ve terörist saldırılarının otel hisse senedi fiyatlarına etkisinin oldukça zayıf olduğunu göstermiştir.

Veri zarflama analizi kullanan Hwang \& Cheng (2003 ) 1998 yllinda 45 otelin yönetimsel performansını ve 1994-1998 döneminde etkinliğini ölçmüşlerdir. Çalışma bulguları, yönetim stilleri ve müşteri kaynaklarındaki farklar sebebiyle etkinli değişiminde anlamlı farklılıklar bulunduğunu göstermektedir. Buna ek olarak Tayvan'daki uluslararası turist otellerinin yönetsel etkinliğinin otel uluslararasılaşma seviyesine bağlı olduğunu göstermektedir. Endüstrinin yönetsel etkinlik ve etkinlik değişimine bağlı olarak altı gruba ayrılabileceğini ve bu altı grup için etkin yönetim stratejilerinin geliştirildiğini belirtmişlerdir.

Ünlü \& Saygın (2014) BIST'te 2012 yılında işlem gören 10 adet turizm şirketinin piyasa katma değeri ve arındırılmış ekonomik katma değerlerini hesaplayıp, hissedar değeri ve piyasa katma değeri yaratıp yaratmadıklarını inceledikleri çalışmada turizm şirketlerinin 4 adedinin hissedarlara katma değer yarattığını ancak ortalama olarak diğer şirketlerin bu performansı gösteremediğini belirlemişlerdir.

Akgün \& Temür (2016) 2010-2015 döneminde BIST ulaştırma endeksinde yer alan 2 havayolu şirketinin finansal performansını TOPSIS yöntemi ile değerlendirmişlerdir. En iyi finansal performans 2012 yılında THY'ye aitken, 2013 ve 2014 y1llarında Pegasus şirketinin olduğu belirlenmiştir. 2013 yılında Pegasus şirketinin borsaya kayıtlanmasının finansal performansını artırdığııı ifade etmişlerdir.

Karadeniz \& Kahiloğulları (2013) Akdeniz bölgesinde bulunan 191 turizm işletme belgeli beş yıldızlı otellerde kullanılan finansal oranların, kullanım sıklığı ve önem derecesini araştırmışlardır. Çalışma bulgularına göre otellerin en sık otel faaliyet oranını önemsediklerini belirlemişlerdir. Buna ek olarak otellerin nakit oranı, borçlanma oranı, alacak devir hızı, faaliyet karlılı̆̆ı, net kar marjı, odabaşına gelir ve oda fiyatının da önemsedikleri finansal oranlar olduklarını ifade etmişlerdir. 
Kahiloğulları \& Karadeniz (2015) Avrupa'dan 51 ve Türkiye'den 12 adet borsaya kayıtlı konaklama işletmesinin 2011-2013 döneminde finansal yapılarını oran analizi ile tespit etmeyi amaçlamışlardır. Çalışma sonucunda Avrupa konaklama işletmelerinin yabancı kaynakla finansmanı, Türk konaklama şirketlerinin ise çoğunlukla öz kaynak ile finansmanı seçtiklerini ifade etmişlerdir. Vade yapısı açısından yabancı kaynak ise, Avrupa şirketleri uzun vadeli Türk şirketleri ise kısa vadeli yabancı kaynak kullanmayı seçtiklerini tespit etmişlerdir. Avrupa şirketleri finansal kiralamayı kullanırken Türk şirketlerinin bu yöntemi tercih etmediklerini ifade etmişlerdir.

Akbulut \& Rençber (2015), imalat endüstrisinde faaliyet gösteren ve BIST'e kayıtlı 32 şirketin 2010-2012 dönemi şirket değerleri ile finansal performanslarını karşılaştırmıştır. Finansal performansı ölçmek amacıyla 10 farklı değişken ve borsa performansı oranı kullanmışlardır. Finansal kriz sonrası dönemde Adana Çimento, Bursa Çelik ve Kelebek mobilya sırasıyla en yüksek finansal performans seviyesine sahip şirketler olarak tespit edilmiştir. Buna ek olarak, şirketlerin borsa performansları ile finansal performansları arasında istatistiksel anlamlı ilişki bulamamışlardır.

\section{YÖNTEM}

$\mathrm{Bu}$ çalışmada BIST'e kayıtlı turizm şirketlerinin finansal performansını araştırmak amacıyla çok ölçütlü karar verme yöntemlerinden TOPSİS yöntemi uygulanmıştır. Yöntem temel olarak pozitif ideal çözüm için en yakın mesafede konumlanan alternatif ile aynı zamanda negatif ideal çözüm açısından en uzak noktada bulunan ideal çözüm alternatifinin seçilmesine dayanmaktadır. Bu yöntemde, ulaşılabilecek bütün en olumlu ölçütlerin bileşimi pozitif ideal çözümü, elde edilebilecek en olumsuz ölçüt değerleri ise negatif ideal çözümü oluşturmaktadır (Y1lmaz, Kaygın \& Gerekan, 2016:613).

TOPSIS yönteminin hesaplanması 6 aşamadan oluşmaktadır.

\section{Aşama: Karar Matrisinin (A) Elde Edilmesi}

Satırlarında üstünlükleri sıralanması düşünülen alternatif karar noktaları (m), sütunlarında da karar için istenilen değerlendirme faktörlerinin (n) bulunduğu matris karar matrisidir. $A_{i j}$ matrisi başlangıç matris olarak oluşturulur ve bu matriste m sayıda alternatif ve $\mathrm{n}$ sayıda kriter yer almaktadır.

\section{Aşama: Standart Karar Matrisi (R)}

Denklem (1)'deki hesaplama ile A karar matrisinde yer alan her bir eleman dönüştürülerek Standart Karar Matrisi elde edilir.

$$
r_{i j}=\frac{a_{i j}}{\sqrt{\sum_{k=1}^{m} a_{k j}^{2}}}
$$

Denklem (1) ile R matrisi elde edilir (Uzun \& Kazan, 2016:102).

\section{Aşama: Ağırlıklı Karar Matrisini (V) Oluşturma}

Aşama üçte öncelikle değerlendirme faktörlerine ait ağırlık değerleri $\left(\mathrm{w}_{\mathrm{i}}\right)$ belirlenir ve burada kritik nokta $\left(\mathrm{w}_{\mathrm{i}}\right)$ değerler toplamının 1 olmasıdır.

$$
\sum_{i=1}^{n} w_{i}=1
$$


Bir önceki aşamada elde edilen matrisin her bir matris elemanı uygulayıcı tarafından tespit edilmiş olan $\left(\mathrm{w}_{\mathrm{i}}\right)$ değeri ile çarpılarak V matrisi oluşturulur (Demireli, 2010:105). Bu aşamada ağırlıkların belirlenmesi uygulayıcı tutumuna göre farklılıklar göstermektedir. Uyguntürk \& Korkmaz (2012) değerlendirme kriteri toplam değerini tüm kriterlerin toplam değerine oranlama yoluyla ağırlıkları belirlerken, Yayar \& Baykara (2012) ise değerlendirme kriterlerini önem derecelerine göre puanlamış ve kriterlerin toplam önem puanı içerisindeki yüzdelik payını ağırlık olarak belirlemiştir. Ömürbek \& Kınay (2013) ve Sakarya \& Aytekin (2013) ise ağırlık katsayılarını eşit olarak kullanmışlardır. $V_{i j}$ matrisi aşağıdaki gibidir (Ergül, 2014: $333)$,

$$
V_{i j}=\left[\begin{array}{ccc}
w_{1} r_{11} & \cdots & w_{n} r_{1 n} \\
\vdots & \ddots & \vdots \\
w_{1} r_{m 1} & \cdots & w_{n} r_{m n}
\end{array}\right]
$$

\section{Aşama: İdeal ( $\left.A^{*}\right)$ ve Negatif İdeal (A-) Çözümleri}

$\mathrm{Bu}$ aşamada, ağırlıklı normal değerleri kullanma yoluyla, ağırlıklı değerlendirme faktörlerinin en büyükleri belirlenir. İdeal çözüm seti

$$
A^{*}=\left\{\left(\max _{i} v_{i j} \mid j \in J\right),\left(\min _{i} v_{i j} \mid j \in J^{\prime}\right\}\right.
$$

denkliğine göre belirlenir. Burada $J$ fayda kriteri ve $J^{\prime}$ ise maliyet kriteri olarak değerlendirilir. Elde edilen yeni set

$$
A^{*}=\left\{v_{1}^{*}, v_{2}^{*}, \ldots, v_{n}^{*}\right\}
$$

şeklinde gösterilir (Supçiller \& Çapraz, 2011:8).

Negatif ideal çözüm seti ise, $\mathrm{V}$ ağırlıklı karar matrisinin her bir sütununun en küçük değerleri seçilerek tespit edilir. Negatif ideal çözüm seti

$$
A^{-}=\left\{\left(\min _{i} v_{i j} \mid j \in J\right),\left(\max _{i} v_{i j} \mid j \in J^{\prime}\right\}\right.
$$

formülü yardımıyla bulunur ve yeni set

$$
A^{-}=\left\{v_{1}^{-}, v_{2}^{-}, \ldots, v_{n}^{-}\right\}
$$

şeklinde gösterilebilir (Şimşek vd., 2015:141).

\section{Aşama: Ayırım Ölçülerinin Hesaplanması}

Euclidian Uzaklık Yaklaşımı kullanılarak, her bir karar noktasına ait ideal ve negatif ideal çözüm noktalarına sapmaları belirlenir. Buradan elde edilen karar noktaları için İdeal Ayırım $S_{i}^{*}$ ve Negatif İdeal Ayırım Ölçüsü $S_{i}^{-}$belirlenir. İdeal ayırım ölçüsü

$$
S_{i}^{*}=\sqrt{\sum_{j=1}^{n}\left(v_{i j}-v_{j}^{*}\right)^{2}}
$$

formülüne göre, negatif ideal ayırım ölçüsü

$$
S_{i}^{-}=\sqrt{\sum_{j=1}^{n}\left(v_{i j}-v_{j}^{-}\right)^{2}}
$$

formülüne göre bulunur (Samut, 2014:61).

6.Aşama: İdeal Çözüme Göre Göreceli Yakınlık Hesabı 
TOPSIS yönteminin son aşamasında, pozitif ideal ve negatif ideal ayrım ölçülerinden faydalanılarak, karar noktalarının he birinin ideal çözüme yakınlığı; toplam ayrım ölçüsü içerisinde negatif ayrım ölçüsünün payı ile ölçülmektedir. Göreceli yakınlıklar,

$$
C_{i}^{*}=\frac{S_{i}^{-}}{S_{i}^{-}+S_{i}^{*}}
$$

formülünden bulunur (Ömürbek vd., 2014: 195).

$C_{i}^{*}$ değeri, 0 ile 1 aralığında değer alır, $C_{i}^{*}$ için bulunan sonucun 0 olması negatif ideal çözüme mutlak yakınlığını, $C_{i}^{*}$ sonucunun 1 bulunması ise ideal çözüme mutlak yakınlığını ifade etmektedir (Karim \& Karmaker, 2016: 10). Bu aşamada $C_{i}^{*}$ sonuçlarına göre alternatif karar noktaları yüksekten düşüğe dizilip önem sıralaması gerçekleştirilir.

\section{VERILERİN TOPLANMASI VE ANALIZİ}

Bu çalışmada BIST'e kote olmuş turizm sektöründe faaliyet gösteren 13 adet turizm şirketi ele alınmıştır. Analize alınan şirketlerin listesi Tablo 1'de sunulmuştur.

\section{Tablo 1: BİST Ulusal Turizm Sektörü}

\begin{tabular}{cll}
\hline Sıra & BİST Kodu & Şirketin Adı \\
\hline 1 & AYCES & Altınyunus Çeşme Turistik Tesisler A.Ş. \\
\hline 2 & AVTUR & Avrasya Petrol ve Turistik Tesisler Yatırımlar A.Ş. \\
\hline 3 & ETILR & Etiler Gıda ve Ticari Yatırımlar Sanayi ve Ticaret A.Ş. \\
\hline 4 & KSTUR & Kuştur Kuşadası Turizm Endüstri A.Ş. \\
\hline 5 & MAALT & Marmaris Altınyunus Turistik Tesisler A.Ş. \\
\hline 6 & MARTI & Martı Otel İşletmeleri A.Ş. \\
\hline 7 & MERIT & Merit Turizm Yatırım ve İşletme A.Ş. \\
\hline 8 & METUR & Metemtur Otelcilik ve Turizm İşletmeleri A.Ş. \\
\hline 9 & NTTUR & Net Turizm Ticaret ve Sanayi A.Ş. \\
\hline 10 & PKENT & Petrokent Turizm A.Ş. \\
\hline 11 & TEKTU & Tek-Art İnşaat Ticaret Turizm Sanayi ve Yatırımlar A.Ş. \\
\hline 13 & ULAS & Ulaşlar Turizm Yatırımları ve Dayanıklı Tüketim Malları Ticaret Pazarlama A.Ş. \\
\hline
\end{tabular}

Kaynak: https://www.kap.org.tr/tr/Sektorler

Söz konusu turizm şirketlerinin 2015 y1lına ait aktif büyüklükleri ve net satışlarıyla ilgili bilgiler Şekil 1 ve Şekil 2'de görülmektedir. 


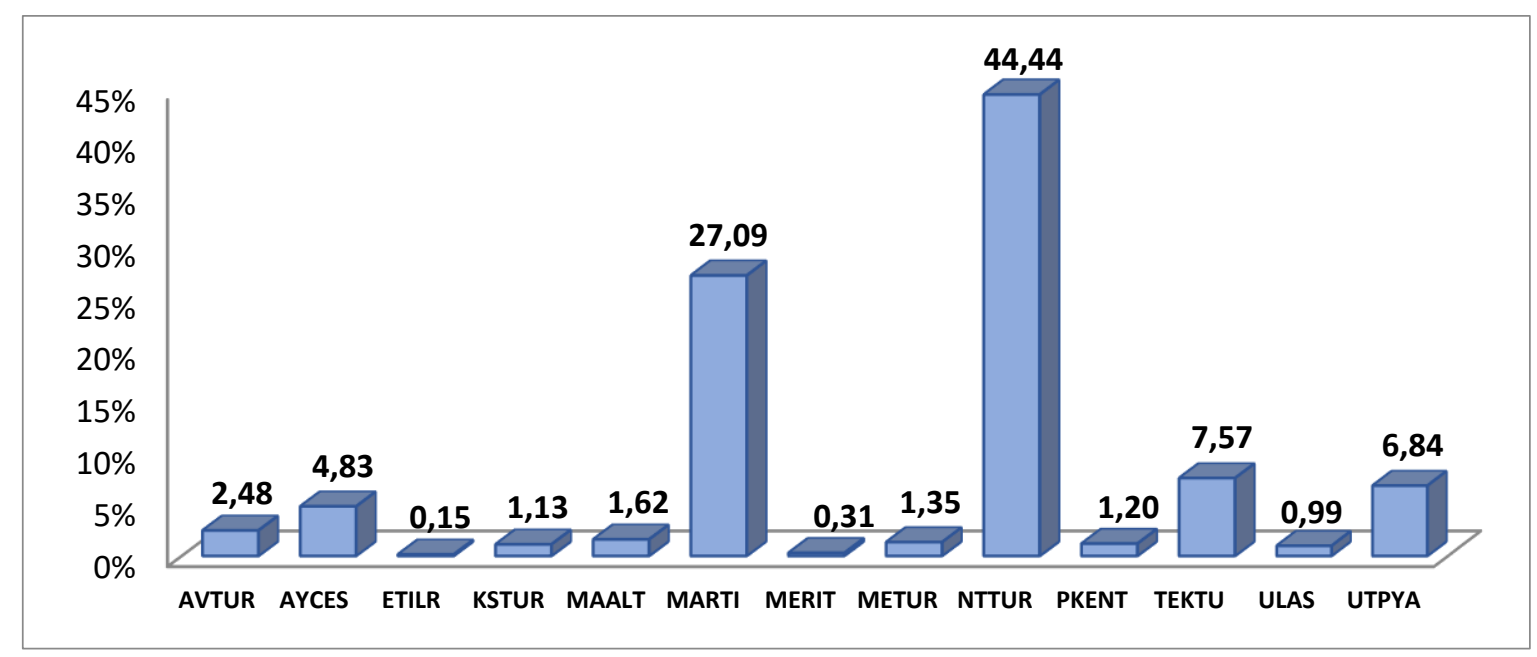

Şekil 1: 2015 yılında BİST’teki Turizm İşletmelerinin Aktif Büyüklükleri

Kaynak: www.kap.org.tr

BIST Turizm Sektöründe faaliyet gösteren firmaların aktif toplamı 3,68 milyar TL'dir. Şekil 1'de ise şirketlerin aktif toplamı içerisindeki oransal payları görülmektedir. Şekil 1'den anlaşılacağı gibi turizm şirketlerinin aktiflerinin büyük bir kısmı $(\% 44,44)$ NTTUR şirketine ait olup, \%27,09'luk pay MARTI ve \%7,57'lik pay ise TEKTU'ya aittir.

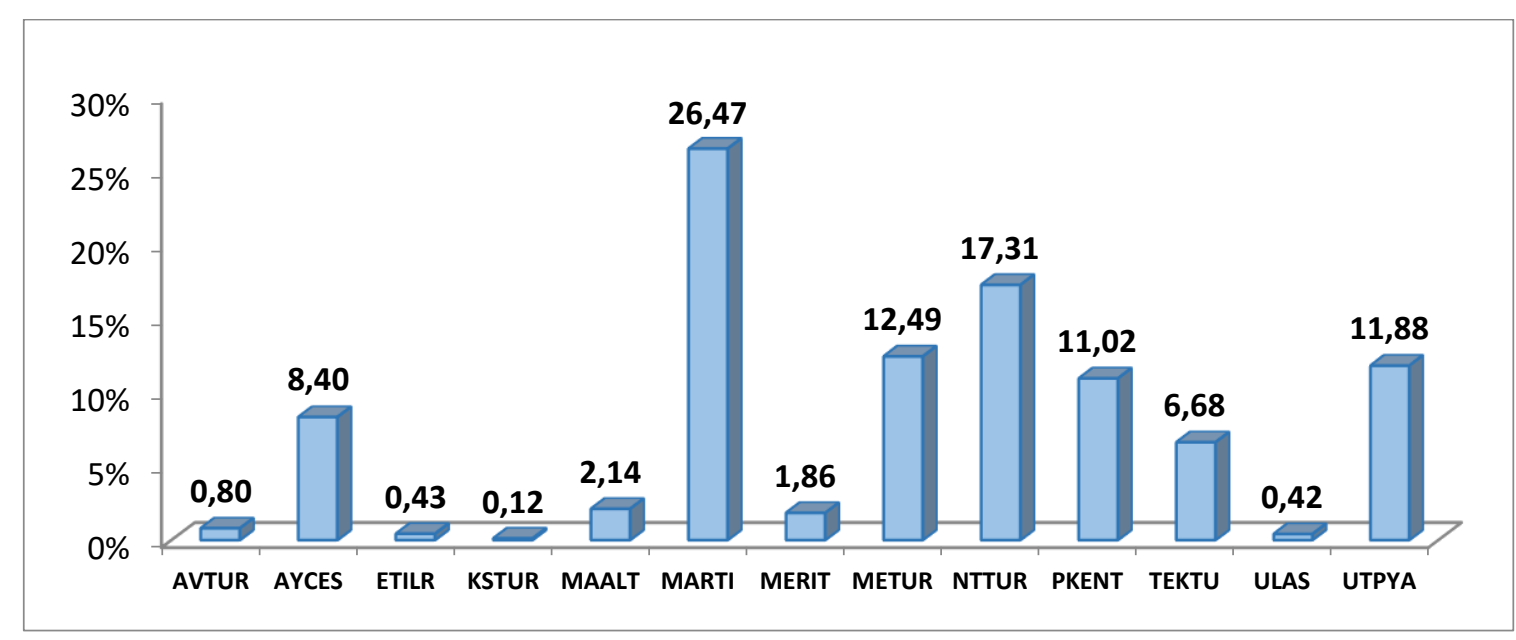

Şekil 2: 2015 yılında BİST’teki Turizm İşletmelerinin Net Satış Hacimleri

Kaynak: www.kap.org.tr

BIST'te faaliyet gösteren turizm şirketlerinin toplam satışları ise 316 milyon TL'dir. Şirketlerin net satışlar toplamı içerisindeki oransal payları Şekil 2'de görülmektedir. Net satışların \%26,47'si MARTI, \%17,31'i NTTUR ve \% 12,49'u ise METUR'a aittir.

Çalışma analizi için kullanılan 12 tane finansal oran Tablo 2'de sunulmuştur. 
Tablo 2: Analizde Kullanılan Finansal Rasyolar

\begin{tabular}{|c|c|c|}
\hline $\begin{array}{l}\text { Rasyo } \\
\text { Grubu }\end{array}$ & Rasyo Adı & Açıklama \\
\hline \multirow{3}{*}{$\begin{array}{l}\text { Likidite } \\
\text { Oranları }\end{array}$} & Cari Oran & Dönen Varlıklar / Kısa Vadeli Yabancı Kaynaklar \\
\hline & Asit Test Oranı & Dönen Varlıklar - Stoklar / Kısa Vadeli Yabancı Kaynaklar \\
\hline & Nakit Oranı & Nakit ve Benzerleri / Kısa Vadeli Yabancı Kaynaklar \\
\hline \multirow{3}{*}{$\begin{array}{l}\text { Faaliyet } \\
\text { Oranları }\end{array}$} & Alacak Devir Hızı & Net Satışlar / Ticari Alacaklar \\
\hline & Özsermaye Devir Hızı & Net Satışlar / Özsermaye \\
\hline & Net İşletme Sermayesi Devir Hızı & Net Satışlar / (Dönen Varlıklar - Kısa Vadeli Yabancı Kaynaklar) \\
\hline \multirow{2}{*}{$\begin{array}{l}\text { Kârlılık } \\
\text { Oranları }\end{array}$} & Özsermaye Kârlılığ1 & Net Kâr / Özsermaye \\
\hline & Net Kâr Marjı & Net Kâr / Net Satışlar \\
\hline \multirow{4}{*}{$\begin{array}{l}\text { Mali Yap1 } \\
\text { Oranlar1 }\end{array}$} & & Kısa Vadeli Yabancı Kaynaklar / Toplam Aktifler \\
\hline & & Uzun Vadeli Yabanc1 Kaynaklar / Toplam Aktifler \\
\hline & & Özsermaye / Toplam Aktifler \\
\hline & Faiz Karşılama Oranı & $\begin{array}{l}\text { Vergi Öncesi Kâr + Faiz (Finansman) Giderleri / Faiz } \\
\text { (Finansman) Giderleri }\end{array}$ \\
\hline
\end{tabular}

Kaynak: Ergül (2014), Özçelik \& Kandemir (2015), Temizel \& Bayçelebi (2016).

Söz konusu turizm şirketlerinin 2011-2015 dönemine ait verileri Kamuyu Aydınlatma Platformu (KAP)'nun www.kap.gov.tr sitesinden temin edilmiştir. Söz konusu veriler, firmaların mali tablolarından faydalanarak likidite, faaliyet, kârlılık ve mali yapı rasyoları gibi dört rasyo grubunda gerek literatür taramalarında, gerekse piyasa kullanımı açısından en fazla kullanılan rasyolar oluşturulmuştur. Ancak bazı turizm işletmelerinin stok kalemleri bulunmadığ için Stok Devir Hızı rasyosu bu çalışmada kullanılmamıştır. Yukarıdaki Tablo 2'de gösterilen finansal oranlar yardımıyla turizm şirketlerinin performansları bulgular bölümünde derecelendirilmiştir.

\section{BULGULAR}

Çalışmada TOPSİS yöntemine göre, 13 tane turizm şirketi ile karar noktası ve 12 tane finansal oran ile değerlendirme faktörü ele alınarak ilk matris oluşturulmuştur. Ele alınan değerlendirme kriterlerinin ağırlıkları 100 üzerinden oran grupları arasında eşit (\%25) olarak paylaştırılmıştır. Her oran grubuna giren oranların ağırlığ 1 ise 0,25 'in grup içi toplam oran sayısına bölünmesi ile elde edilmiştir. TOPSIS yönteminde söz edilen aşamalar adım adım uygulanarak aşağıdaki sonuçlar elde edilmiştir. Bulunan göreli yakınlık skorları, büyüklük değeri bakımından sıralanarak karar noktalarının önem sıraları Tablo 3'de sunulmuştur. 
Tablo 3: 2011-2015 Yıllar Arasında BIST'teki Turizm Şirketlerinin Sıralamaları

\begin{tabular}{|c|c|c|c|c|c|c|c|c|c|c|}
\hline \multirow{3}{*}{$\begin{array}{l}\text { Turizm } \\
\text { Şirketleri }\end{array}$} & \multicolumn{10}{|c|}{ Yillar } \\
\hline & \multicolumn{2}{|c|}{2011} & \multicolumn{2}{|c|}{2012} & \multicolumn{2}{|c|}{2013} & \multicolumn{2}{|c|}{2014} & \multicolumn{2}{|c|}{2015} \\
\hline & $\begin{array}{c}\text { Puan } \\
(\%)\end{array}$ & $\begin{array}{l}\text { Sira } \\
\text { No }\end{array}$ & $\begin{array}{c}\text { Puan } \\
(\%)\end{array}$ & $\begin{array}{c}\text { Sira } \\
\text { No }\end{array}$ & $\begin{array}{c}\text { Puan } \\
(\%)\end{array}$ & $\begin{array}{l}\text { Sira } \\
\text { No }\end{array}$ & $\begin{array}{c}\text { Puan } \\
(\%)\end{array}$ & $\begin{array}{c}\text { Sira } \\
\text { No }\end{array}$ & $\begin{array}{c}\text { Puan } \\
(\%)\end{array}$ & $\begin{array}{c}\text { Sira } \\
\text { No }\end{array}$ \\
\hline AVTUR & 76,2 & 12 & $30,0^{\text {** }}$ & 13 & 74,8 & 10 & 91,0 & 3 & 56,6 & 10 \\
\hline AYCES & 79,9 & 11 & 56,2 & 11 & 75,5 & 9 & 81,2 & 4 & $41,5^{* *}$ & 13 \\
\hline ETILR & 85,6 & 6 & 59,7 & 9 & 78,6 & 6 & $35,0^{* *}$ & 13 & 61,0 & 7 \\
\hline KSTUR & 94,4 & 4 & 77,5 & 3 & 86,0 & 3 & 79,2 & 7 & 87,3 & 2 \\
\hline MAALT & 96,2 & 3 & 82,3 & 2 & $100^{*}$ & 1 & 97,3 & 2 & 77,2 & 3 \\
\hline MARTI & 81,7 & 10 & 61,0 & 8 & 78,5 & 7 & 66,9 & 11 & 43,7 & 12 \\
\hline MERIT & 83,8 & 9 & 67,6 & 5 & 84,4 & 4 & 80,4 & 5 & 66,4 & 5 \\
\hline METUR & $45,6^{* *}$ & 13 & $100^{*}$ & 1 & $40,8^{* *}$ & 13 & 64,5 & 12 & $100^{*}$ & 1 \\
\hline NTTUR & $100^{*}$ & 1 & 71,3 & 4 & 90,5 & 2 & $100^{*}$ & 1 & 70,0 & 4 \\
\hline PKENT & 83,9 & 8 & 54,7 & 12 & 76,4 & 8 & 79,6 & 6 & 58,1 & 9 \\
\hline TEKTU & 97,1 & 2 & 64,3 & 7 & 79,8 & 5 & 72,3 & 9 & 66,3 & 6 \\
\hline ULAS & 89,5 & 5 & 65,1 & 6 & 71,6 & 11 & 79,0 & 8 & 46,5 & 11 \\
\hline UTPYA & 84,6 & 7 & 59,2 & 10 & 69,9 & 12 & 71,1 & 10 & 59,0 & 8 \\
\hline
\end{tabular}

* en yüksek performansı gösteren turizm şirketi, ** en düşük performansı gösteren turizm şirketi.

Çalı̧̧mada dikkate alınan her bir yıla ait turizm şirketlerinin performans sıralaması aşağıdaki Şekil 3-7'de ayrıntılı bir şekilde görülmektedir.

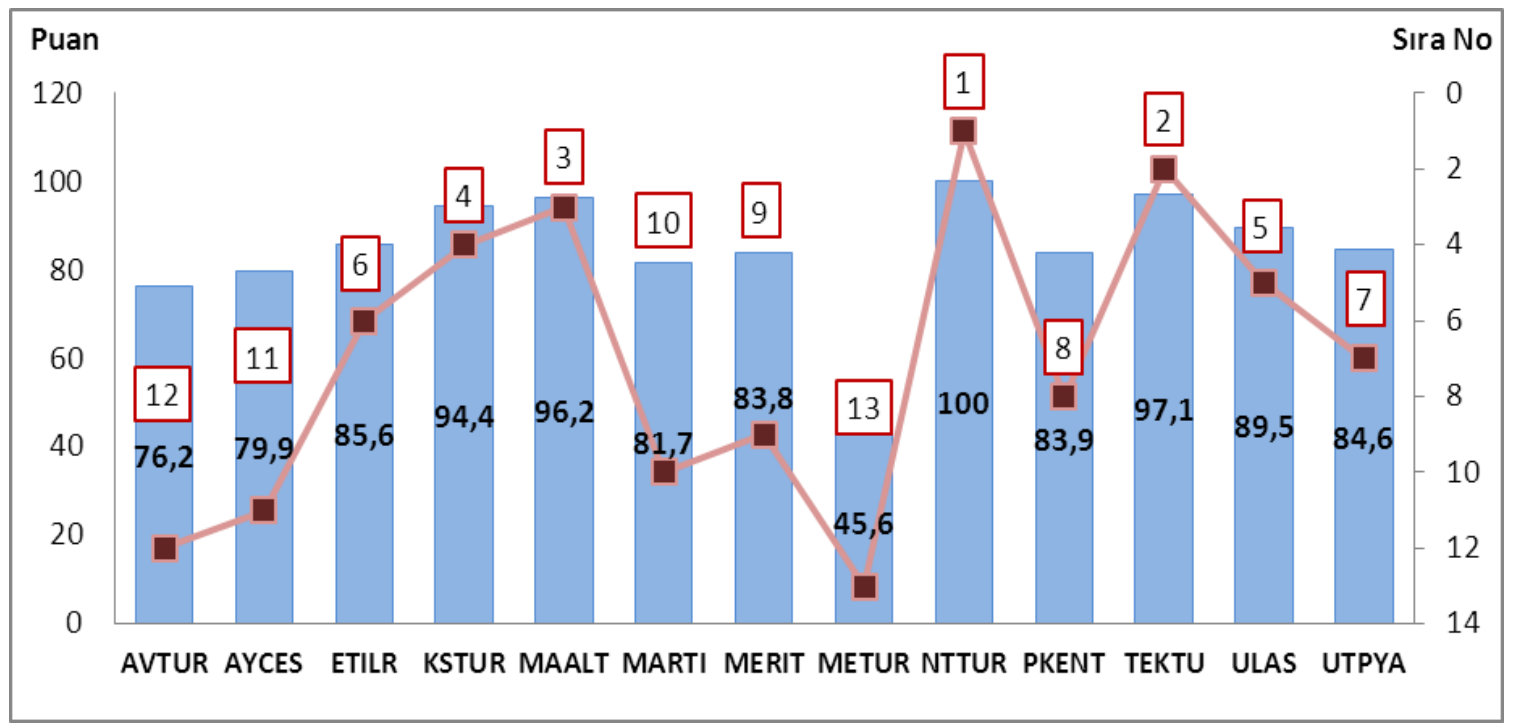

Şekil 3: BIST’teki Turizm Şirketlerinin 2011 Yılına Ait Sıralamaları

2011 yılı itibariyle değerlendirilmesi yapılan turizm şirketlerinin arasında en yüksek performansı NTTUR, en düşük performansı ise METUR göstermiştir. İkinci sırayı TEKTU, 
üçüncü sırayı MAALT alırken, dördüncü sırada KSTUR ve beşinci sırada ise ULAS yer almıştır. TURSAB verilerine göre 2011 yılında Yunanistan ve Misır'da gerçekleşen halk olaylarından dolayı Türk turizm sektörüne talep artmış, turist sayısı 31,46 milyona yükselmiş ve satışlarda ciddi artı̧̧ gözlenmiştir. Bu olay tüm sektörü olumlu etkilerken, en olumlu etkilenen firma ise NTTUR olmuştur. İlgili yıl incelendiği zaman, satışlarını yükselten NTTUR kârlılık rasyoları, TEKTU ise ödeme gücü rasyoları açısından diğer firmalara göre daha avantajlı konum sağlamışlardır. Ergül (2014) BIST’e kayıtlı 7 turizm şirketinin (AYCES, FVORI, MAALT, METUR, NETTUR, PKENT, TEKTU) 2005-2012 dönemine ait 11 finansal oranını kullanarak en yüksek finansal performansa sahip olanını belirlemek için ELECTRE ve TOPSIS yöntemlerini kullanmıştır. 2005 ve 2006, 2011 ve 2012 yıllarında MAALT, 2007 ve 2010'da NETTUR, 2008 ve 2009'da PKENT şirketlerinin finansal performanslarının başarılı olduğunu tespit etmiştir. Bu çalışmada ise 13 turizm şirketi arasında 2011 yılında NTTUR ve 2012 yılında METUR'un en yüksek finansal performansa sahip olduğu belirlenmiştir.

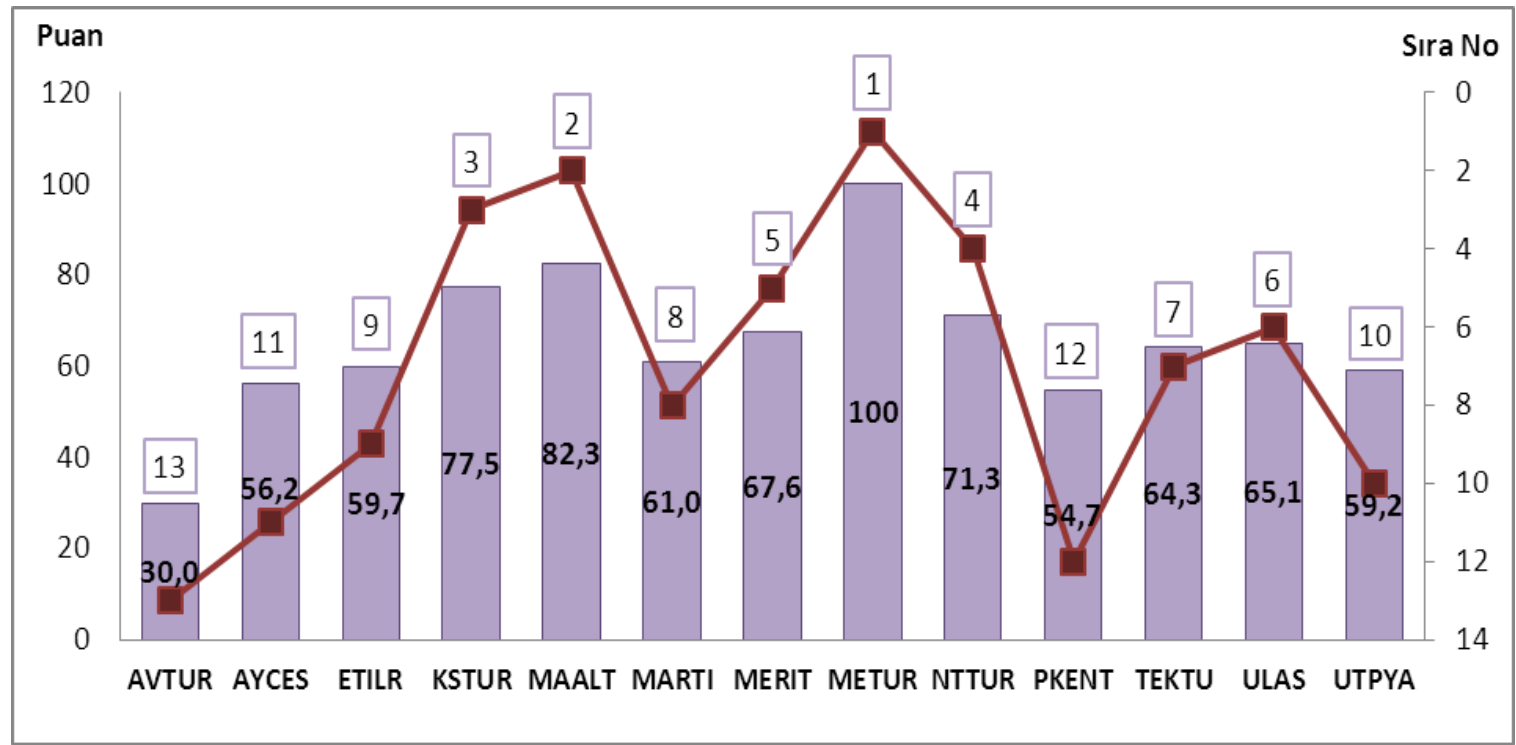

Şekil 4: BIST’teki Turizm Şirketlerinin 2012 Yıla Ait Sıralamaları

2012 yılında 2011 yılında meydana gelen olayların etkisi ortadan kalktığı için sektörde bir daralma meydana gelmiştir. Ortaya çıkan yeni durumda TURSAB verilerine göre turist sayıs1 yaklaşık aynı kalırken (2012 yılı turist sayısı 31.782.832) gelirlerde bir azalma söz konusu olmuştur. Bu gelişmeler çerçevesinde sektör performans sıralamasında birinci sırada METUR yer alırken son sırada ise AVTUR bulunmaktadır. İkinci sırada ise MAALT, sonrasında KSTUR ve NTTUR yer almaktadır. 2012 yılında METUR firmasının ilk sırada bulunmasının en büyük nedeni kârlılık rasyolarının önceki yıla göre olağanüstü iyi çıkmasından kaynaklanmıştır. 2012 yılında önceki yılın zararı kapatılmakla birlikte olağanüstü kâr ortaya çıktığı gözlenmektedir. 


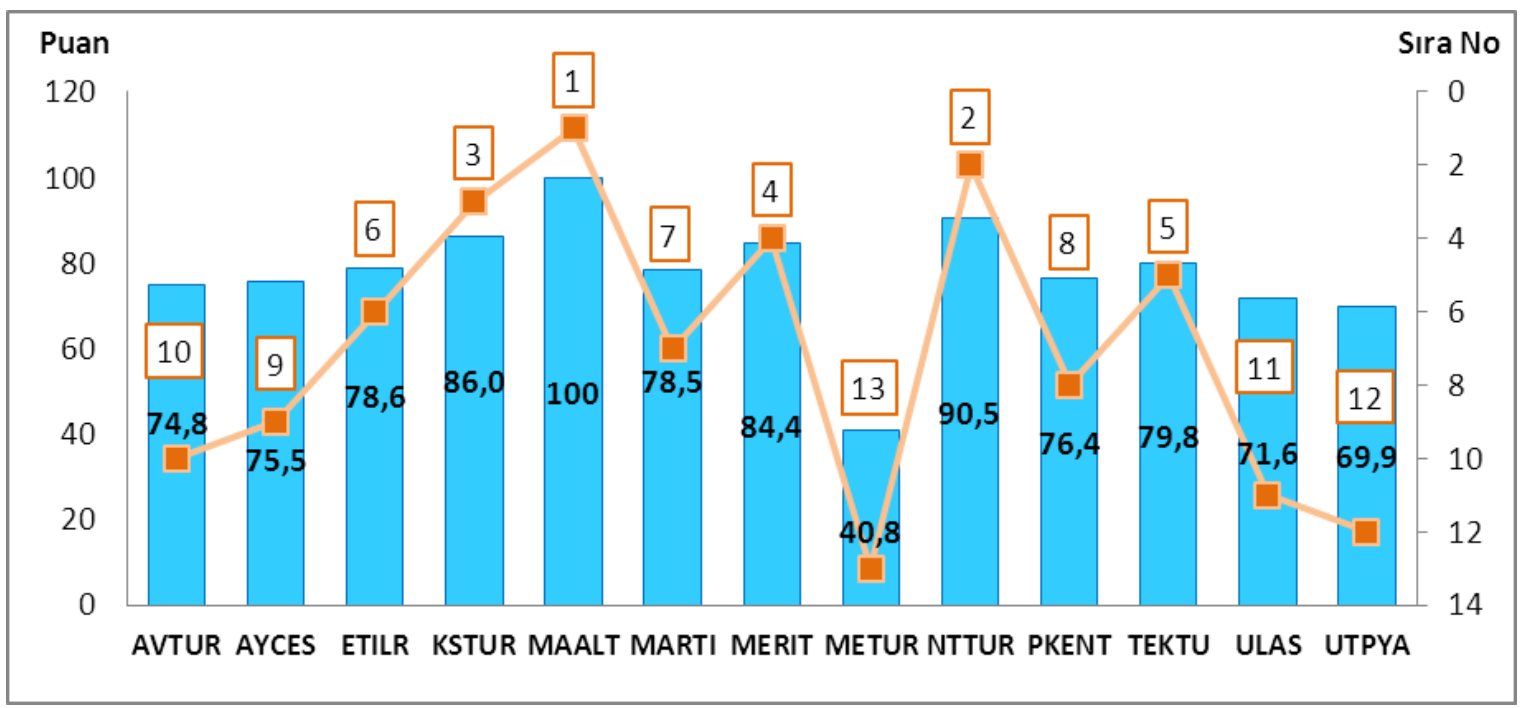

Şekil 5: BIST’teki Turizm Şirketlerinin 2013 Yıla Ait Sıralamaları

2013 yılında en yüksek performansın MAALT'a ait olduğu belirlenirken en düşük performans ise METUR'a aittir. İkinci sırayı NTTUR, üçüncü sırayı KSTUR, dördüncü sırayı MERIT ve beşinci sırayı TEKTU almıştır. Gecmiş yıllar incelendiğinde MAALT firmasının istikrarlı biçimde iyi finansal oranlara sahip olduğu tespit edilmiştir. MAALT firması istikrarlı seyrini sürdürürken diğer firmaların performanslarında bozulmalar görülmektedir. Bunun sonucu olarak 2013 yılı değerlendirildiğinde MAALT firması yılı birinci sırada tamamlamıştır. Diğer firmalar da performanslarına göre sıralanmışlardır. 2013 yılında en büyük sapma ULAS firmasında ortaya çıkmış, 2012 yılında 6. sırada iken 2013 yılında 11. sıraya gerilemiştir. İlgili yıllar rasyoları incelendiğinde ULAS firmasının 2012 yılında zarar görüntüsü daha üst noktalara ulaşmış ve firma aşırı zararlı hale gelmiştir.

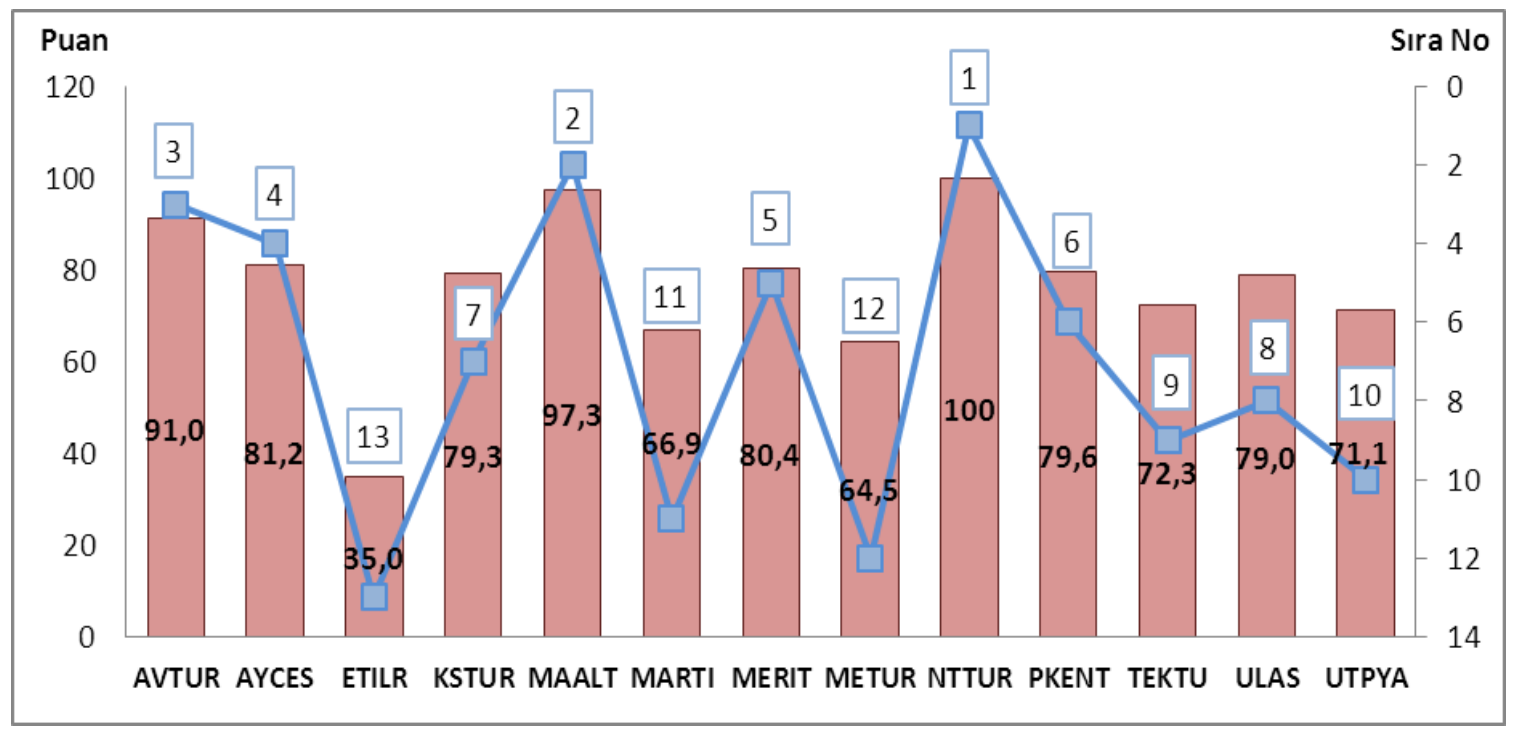

Şekil 6: BIST’teki Turizm Şirketlerinin 2014 Yıla Ait Sıralamaları 
2014 yılında ilk beşe giren şirketler sırayla NTTUR, MAALT, AVTUR, AYCES ve MERIT'tir. Son sırayı ise ETILR almıştır. NTTUR ilk sırada bulunurken, MAALT firması daha önceki yıllarda gösterdiği istikrarlı performansını devam ettirmiştir. 2014 yılında AVTUR firması önceki yıla göre performansını olağanüstü artırmış ve üçüncü sıraya yükselmiştir. Bu performans artışına neden olan en önemli unsurun 2014 yılında gelirlerin ve kârın büyük oranda artması gösterilebilir. AVTUR 2014 yılında yatırımlarından büyük miktarda gelir elde etmiş ve firma kârı yukarıya taşınmıştır. Bu da firmanın performansını diğer firmalara göre ön plana çıkarmaktadır.

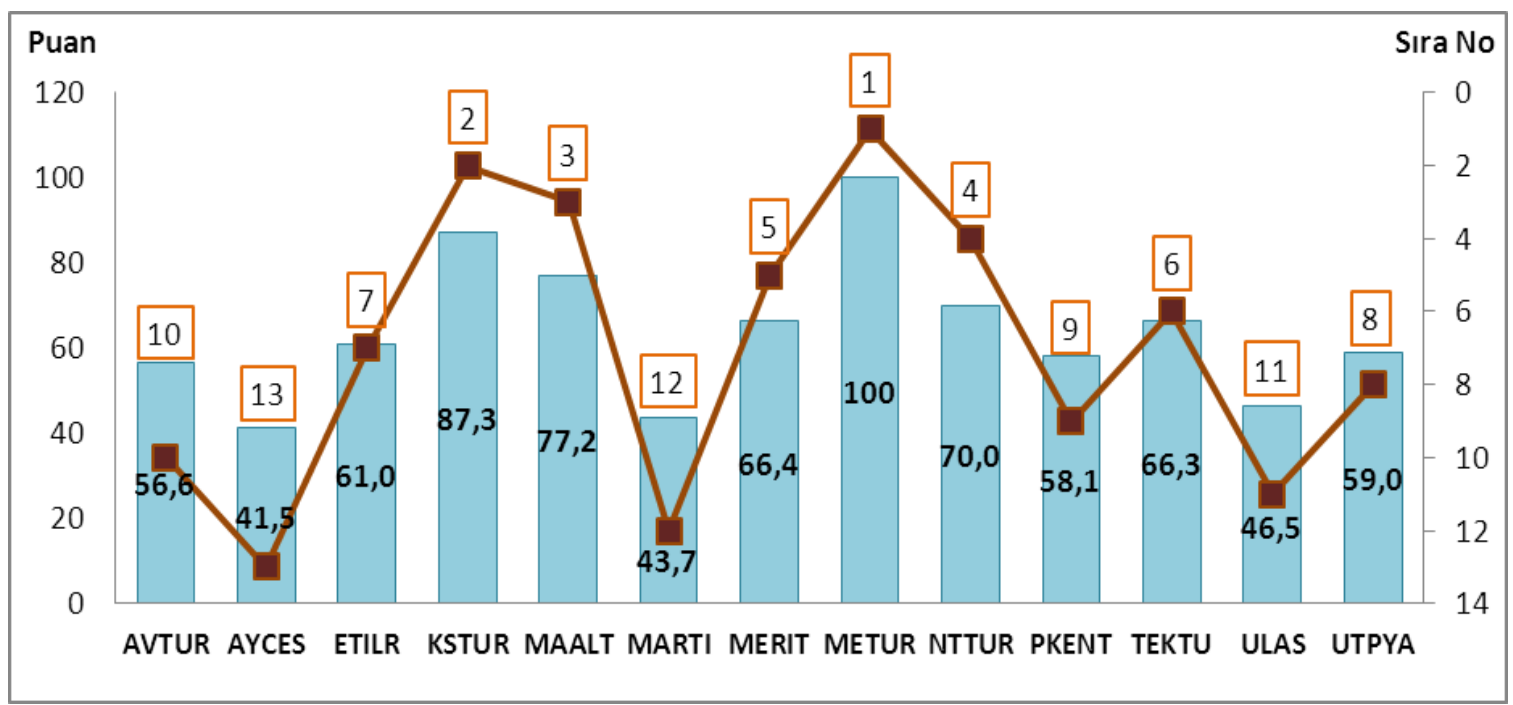

Şekil 7: BIST’teki Turizm Şirketlerinin 2015 Yıla Ait Sıralamaları

2015 yılı itibarıyla en yüksek performansı METUR, en düşük performansı ise AYCES göstermiştir. Diğer sıralamalar incelendiğinde; ikinci sırada KSTUR, üçüncü sırada ise MAALT'ın bulunduğu görülmektedir. NTTUR dördüncü sırayı almış, MERIT ise beşincilikte kendisine yer bulabilmiştir. Altıncı sırayı TEKTU alırken, ETILR yedinci, UTRYA ise sekizinci olmuştur. Dokuzuncu sırayı PKENT alırken, onuncu sırayı da AVTUR almıştır. On birinci sırayı performans açısından ULAS, on ikinci sırayı MARTI işgal etmiştir. 2015 yılı itibarıyla en çarpıcı performansı METUR firması göstermiştir. Firma önceki iki yıl performans olarak son sırada bulunurken, 2015 yılında ilk sıraya yerleşmiştir. MAALT ise 3. sıraya gerilemiştir. Firma rasyoları incelendiğinde METUR firmasının önceki yıllara göre kârlılığını artırdığı görülmüştür. KSTUR firması ise gelirlerini ve kârlılı̆̆ını artırarak 2. sıraya yerleşmiştir. 2015 y1lı KSTUR mali tabloları incelendiğinde önemli tutarda kira geliri elde ettiği ve kârlılığına olumlu yansıttığı görülmüştür.

2011-2015 yılları arasında yüksek performans gösteren NTTUR 2011, 2013 ve 2014 yılında satışlarının yüksek olması kârlılık rasyolarının artmasına neden olmuştur. 5 yıl içerisinde NTTUR ödeme gücü rasyolarını ortalama olarak 0,25'ten 4,59'a yükseltmiştir. Alacak devir hızı rasyosu 5,17 iken 11,22'e ulaşmıştır. Sadece 2015 yılında kârlılık oranlarında azalış görülmektedir. Bu da NTTUR'un esas faaliyetten sağlanan yüksek satışlarına rağmen yüksek genel yönetim ve pazarlama giderleri ve yatırım faaliyetleri giderlerine sahip olmasından kaynaklanmaktadır.

2011 yılında son sirada yer alan METUR 5 yıl içerisinde dalgalı performans göstermiştir. 2012 yılı ve 2015 y1lı arasında METUR satışlarını sürekli artırarak kar elde 
etmiş̧tir. 2015 yılında diğer yıllara göre ele alınan rasyolarında yükseliş görülmektedir. METUR 2015 yılında dönen varlıklarından nakit ve nakit benzerlerini artırarak, kısa vadeli yükümlülüklerini azaltmış ve uzun vadeli borçlarını artırdığı gözlenmektedir. 2011 yılına göre özellikle cari oran yaklaşık 5 kat, nakit oranı 11 kat, alacak devir hızı 4,7 kat artmıştır. Özçelik \& Kandemir (2015) çalışmasında Türk turizm şirketlerinin (AYCES, MAALT, METUR, NTTUR, PKENT, TEKTU, UTPYA) 2010-2014 dönemi için finansal performanslarını likidite, kaldıraç, kârlılık ve faaliyet oranları yardımıyla değerlendirmiştir. 2010-2011 yıllarında en yüksek performans TEKTU, ikinci METUR ve MAALT, 2012-2014 yıllarında MAALT, ikinci METUR ve PKENT şirketlerinin sergilediğini bulmuştur. Bu çalışmada ise turizm işletmelerinden NTTUR ve MAALT'in en iyi performansı gösterdikleri tespit edilmiştir. PKENT ise ele alınan 13 turizm şirketi arasında orta sıralarda yer almaktadır. METUR'un ise son sıradan ilk sıraya, ilk sıradan son sıraya doğru oldukça dalgalı bir eğilim gösterdiği belirlenmiş̧tir.

2015 yılında 12. sırada olan MARTI da 5 yıl içerisinde dalgalı performans göstermiştir. Bunun temel nedeni MARTI şirketinin otel ve gayrimenkul projelerini geliştirmeye yönelik çalışmalarını sürdürmesidir. Her yıl satışlarını artırmasına rağmen finansman giderlerinin ve esas faaliyetlerden diğer giderlerinin çok yüksek olmasından dolayı MARTI bilançosunda her yıl zarar göstermiştir.

2015 yılında son sırada bulunan AYCES, ele alınan 5 yıllık dönem içerisinde 2015 yılına kadar yukarıya doğru yükselen, fakat 2015 yılında uzun vadeli yükümlülüklerinin artması, dönemin sonunda zarar etmesi ve net çalışma sermayesi devir hızının negatif olmasından dolayı turizm işletmeleri arasında en düşük performansı göstermiştir. Satışları yıldan yıla artış göstermesine rağmen AYCES şirketinin, net işletme sermayesi negatif olmasından dolayı net işletme sermayesi devir hızı da olumsuz etkilenmiştir. Aynı zamanda işletmenin zararının da artması performansının çok kötü seviyede çıkmasına neden olmuştur.

Çalışma genel olarak değerlendirildiğinde, 2011-2015 dönemi itibariyle MAALT ve NTTUR şirketlerinin iyi performans gösteren, METUR ve TEKTU'nun ise sürekli dalgalanma gösteren turizm şirketleri olduğu belirlenmiştir. Bazı şirketlerin finansal performansları bu dönemde yükseliş eğiliminde olurken, bazılarının ise performanslarında azalma olduğu gözlemlenmiştir.

\section{SONUÇ VE ÖNERİLER}

Araştırmadan elde edilen sonuçlar değerlendirildiğinde y1llar itibariyle MAALT ve NTTUR şirketlerinin oldukça istikrarlı olduğu görülmektedir. Bu firmaların çalışmada kullanılan verileri de diğer firmalara göre oldukça istikrarlı seyretmiştir. Firmaların özellikle ödeme gücü oranları, devir hızı oranları ve kârlılık oranları diğer firmalara göre daha istikrarlıdır. Çalışmada diğer firmalara göre ciddi dalgalanma gösteren firmalar ise, METUR ve TEKTU olarak göze çarpmaktadır. Bu şirketlerin oranlarında da ciddi dalgalanmalar görülmektedir. Yıllar itibarıyla incelendiğinde ödeme gücü oranları, devir hızı oranları ve kârlılık oranlarında dalgalanmalar görülmektedir. Bu dalgalanmalar turizm şirketlerinin mali yapılarını da olumsuz etkilemiştir.

Çalışmadan elde edilen sonuçlarla ulaşılabilen ve bu alanda yapılan önceki çalışmaların sonuçları karşılaştırıldığında genel olarak benzerlik gösteren sonuçlara ulaşılmıştır.

Literatürdeki çalışma sonuçlarıyla bu çalışmada elde edilen sonuçlar arasında benzerlikler görülmektedir. Farklılaşmanın nedeni de bu çalışmaya alınan örnekten (7 turizm şirketi değil, 13 turizm şirketi ele alındığından) kaynaklanmaktadır. önerilebilir;

$\mathrm{Bu}$ çalışmadan elde edilen sonuçlara göre turizm şirketlerine aşağıdaki hususlar 
- Firmalar ödeme gücü oranlarına önem vermelidir. Başka bir ifade ile firmalar, varlık ve kaynak yapısını oluştururken dikkat etmelidirler. Kısa vadeli borç seviyesini iyi ayarlamalı, bununla birlikte dönen varlık yapısına da dikkat etmelidirler.

- Turizm şirketleri için devir hızı son derece önemlidir. Alacak tahsilatında ve satış politikasında firmaların dikkat etmeleri gerekmektedir. Sezon için satış sözleşmelerini sağlam yapmalılar. Yapılan sözleşmelerden kaynaklanan tahsilat takibini iyi yapmaları gerekmektedir.

- Satış konusunda firmaların çeşitliliğe gitmeleri gerekmektedir. Özellikle bu çeşitlilik coğrafi açıdan olmalıdır. Tek bir coğrafyadan müşteri çekmek yerine, farklı coğrafya insanlarına yönelmeleri gerekmektedir. Bu şekilde hem daha kolay satış yapabilecekler, hem de tahsilat sıkıntısı çekmeyeceklerdir.

- Firmalar satış ve tahsilat konusunda problem yaşamadıkları durumda, kârlılıkları da olumlu etkilenecektir. Kârlılık oranlarına olumlu yansıyan durum firma performansını artıracaktır.

- Turizm şirketleri mali yapılarına da dikkat etmelidir. Yüksek öz kaynak yapısı şirketlerin hisse başı kârlılıklarını olumsuz etkilerken, yüksek miktarlarda borçlanmalar da şirketlerin maliyetlerini ve risklerini artıracaktır. Bu durum ilerledikçe şirketler açısından içinden çıkılamaz durumların oluşmasına neden olacaktır. Nitekim çalışmada aşırı borçlanan turizm şirketlerinin performanslarının iyi çıkmadığı, yıllar itibarıyla çok dalgalı bir performans ortaya koydukları görülmüştür.

\section{KAYNAKÇA}

Akbulut, R. \& Rençber, Ö. F. (2015). BİST’te imalat sektöründeki işletmelerin finansal performansları üzerine bir araştırma. Muhasebe ve Finansman Dergisi, 65, 118-136.

Akgün, M., \& Temür, A. (2016). BIST Ulaştırma Endeksine Kayıtlı Şirketlerin Finansal Performanslarının Topsis Yöntemi İle Değerlendirilmesi. Uluslararası Yönetim İktisat ve İşletme Dergisi, 30, 173-186.

Aydeniz, E. Ş. (2009). Makroekonomik Göstergelerin Firmaların Finansal Performans Ölçütleri Üzerindeki Etkisinin Ölçülmesine Yönelik Bir Araştırma: İMKB’ye Kote Gıda Ve İçecek İşletmeleri Üzerine Bir Uygulama. Marmara üniversitesi Íktisadi ve İdari Bilimler Dergisi, 27(2), 263-278.

Blanke, J., \& Chiesa, T. (2015). The travel \& tourism competitiveness report 2015. The World Economic Forum.

Bulgurcu, B. K. (2012). Application of TOPSIS technique for financial performance evaluation of technology firms in Istanbul stock exchange market. Social and Behavioral Sciences, 62, 1033-1040.

Chen, M. H. (2011). The response of hotel performance to international tourism development and crisis events. International Journal of Hospitality Management, 30(1), 200-212. https://doi.org/10.1016/j.ijhm.2010.06.005

Chou, M. C. (2013). Does tourism development promote economic growth in transition countries? A Panel Data Analysis. Economic Modelling, 33, 226-232.

Çetintaş, H. \& Bektaş, Ç. (2008). Türkiye'de turizm ve ekonomik büyüme arasındaki kısa ve uzun dönemli ilişkiler. Anatolia: Turizm Araştırmaları Dergisi, Cilt 19, Sayı 1, Bahar: 37-44.

Demireli, E. (2010). TOPSIS çok kriterli karar verme sistemi: Türkiye’deki kamu bankaları üzerine bir uygulama. Girişimcilik ve Kalkınma Dergisi, 5(1), 101-112.

Dumanoğlu, S. \& Ergül, N. (2010). İMKB'de işlem gören teknoloji şirketlerinin mali performans ölçümü. Muhasebe ve Finansman Dergisi, 48, 101-111.

Ecer, F., \& Günay, F. (2014). Borsa İstanbul'da İşlem Gören Turizm Şirketlerinin Finansal Performanslarının Gri İlişkisel Analiz Yöntemiyle Ölçülmesi. Anatolia: Turizm Araştırmaları Dergisi, 25(1), 35. https://doi.org/10.17123/atad.vol25iss195016

Ergül, N. (2014). BİST-Turizm sektöründeki şirketlerin finansal performans analizi. Çankırı Karatekin Üniversitesi İktisadi ve İdari Bilimler Fakültesi Dergisi, 4(1), 325-340. 
Gökdeniz, A., \& Erdem, B. (2015). Turizm politikasında ekonomik başarı koşulları ve Ayvalık örneği. Journal of Marmara Social Research/Marmara Sosyal Araşttrmalar Dergisi, (5), 1-32.

https://www.wttc.org/research/economic-research/economic-impact-analysis/

Huang, J. H., \& Peng, K. H. (2012). Fuzzy Rasch model in TOPSIS: A new approach for generating fuzzy numbers to assess the competitiveness of the tourism industries in Asian countries. Tourism Management, 33(2), 456-465.

Hwang, S. N. and Chang, T. Y. (2003). Using Data Envelopment Analysis to Measurement Hotel Managerial Efficiency Change in Taiwan, Tourism Management, 24: 357-369.

İlkuçar, M., \& Çifci, A. (2016). Performance evaluation of electricity generation companies traded on BIST according to the financial parameters through the application of TOPSIS method. International Journal of Social Sciences and Education Research, 2(3), 1010-1021.

Kahiloğulları, S., \& Karadeniz, E. (2015). Halka Açık Konaklama Şirketlerinin Finansal Yapılarının Analizi: Uluslararası Bir Karşılaştırma. Çankırı Karatekin Üniversitesi İIBF Dergisi, 2, 531-548.

Karaatlı, M., Ömürbek, N., \& Köse, G. (2014). Analitik Hiyerarşi Süreci temelli TOPSIS ve VIKOR yöntemleri ile futbolcu performanslarının değerlendirilmesi. Dokuz Eylül Üniversitesi İktisadi ve İdari Bilimler Fakültesi Dergisi, Cilt: 29, Say1: 1, 25-61.

Karadeniz, E., \& Kahiloğulları, S. (2013). Beş Yıldızlı Otel İşletmelerinde Finansal Oranların Kullanımı: Akdeniz Bölgesi'nde Bir Araştırma. Seyahat ve Otel Işsletmeciliği Dergisi, 10(3), 84-106.

Karadeniz, E., Beyazgül, M., Dalak, S., \& Günay, F. (2017). Türk Turizm Sektörünün Finansal Performansının Dikey Analiz Yöntemiyle İncelenmesi: BİST Turizm Şirketleri ve TCMB Sektör Bilançoları Üzerinde Bir Araştırma. Sosyoekonomi, 25(32), 105-105. https://doi.org/10.17233/sosyoekonomi.292117

Karim, R., \& Karmaker C. L. (2016). Machine selection by AHP and TOPSIS methods. American Journal of Industrial Engineering, Vol. 4, No. 1, 7-13.

Morteza, Z., Reza, F. M., Seddiq, M. M., Sharareh, P., \& Jamal, G. (2016). Selection of the optimal tourism site using the ANP and Fuzzy TOPSIS in the framework of Integrated Coastal Zone Management: A case of Qeshm Island. Ocean \& Coastal Management, 130, 179-187.

Ömürbek, N, Karaatlı, M., \& Yetim, T. (2014). Analitik Hiyerarşi Sürecine dayalı TOPSIS ve VIKOR yöntemleri ile ADIM üniversitelerinin değerlendirilmesi. Selçuk Üniversitesi Sosyal Bilimler Enstitüsü Dergisi, 189-207.

Özçelik, H., \& Kandemir, B. (2015). BIST'de işlem gören turizm işletmelerinin TOPSIS yöntemi ile finansal performanslarının değerlendirilmesi. Balıkesir University The Journal of Social Sciences Institute, 18(33), 97-114.

Saldanlı, A., \& Sırma, İ. (2014). TOPSİS yönteminin finansal performans göstergesi olarak kullanılabilirliği. Journal of Marmara University Social Sciences Institute/Öneri, 11(41), 185-202.

Samut, P. K. (2014). İki aşamalı çok kriterli karar verme ile performans değerlendirmesi: AHP ve TOPSIS yöntemlerinin entegrasyonu. Anadolu Üniversitesi Sosyal Bilimler Dergisi, Cilt/Vol.: 14 - Say1/No: 4 (57-68).

Supçiller, A. A., \& Çapraz, O. (2011). AHP-TOPSIS yöntemine dayalı tedarikçi seçimi uygulaması. İstanbul Üniversitesi Iktisat Fakültesi Ekonometri ve İstatistik Dergisi, Say1: 13 (12. Uluslararası Ekonometri, Yöneylem Araştırması, İstatistik Sempozyumu, Özel Sayısı), 1-22.

Şimşek, A., Çatır, O., \& Ömürbek, N. (2015). TOPSIS ve MOORA yöntemleri ile tedarikçi seçimi: turizm sektöründe bir uygulama. Balikesir University Journal of Social Sciences Institute, 18(33), 133-161.

Temizel, F., \& Bayçelebi, B. E. (2016). Finansal oranların TOPSIS sıralaması ile yıllık getiriler arasındaki ilişki: tekstil imalat1 sektörü üzerine bir uygulama. Anadolu University Journal of Social Sciences, 16(2).

TOBB Turizm Sektör Meclisi Turizm Raporu, Y11: 6, Sayı: 11, 2016.

Türkmen, S. Y., \& Çağıll, G. (2012). İMKB'ye kote bilişim sektörü şirketlerinin finansal performanslarının TOPSIS yöntemi ile değerlendirilmesi. Maliye Finans Yazıları, 1(95).

Uygurtürk, H., \& Korkmaz, T. (2012). Finansal performansın TOPSIS çok kriterli karar verme yöntemi ile belirlenmesi: ana metal sanayi işletmeleri üzerine bir uygulama. Eskişehir Osmangazi Üniversitesi İ̈BF Dergisi, 7(2), 95-115.

Uzun, S. \& Kazan, H. (2016). Çok kriterli karar verme yöntemlerinden AHP TOPSIS ve PROMETHEE karşılaştırılması: Gemi inşada ana makine seçimi uygulaması. Journal of Transportation and Logistics, 1(1), 99-113.

Ünlü, U., \& Saygın, O. (2014). Arındırılmış Ekonomik Katma Değer (REVA) Yöntemiyle Performans Ölçümü: Turizm Sektörü Uygulamas1. Muhasebe ve Finansman Dergisi, (63), 139-150. 
Optimum Journal of Economics and Management Sciences, Vo1. 5, No. 1- http://dergipark.ulakbim.gov.tr/usakoeyb/

Erdoğan and Yamaltdinova - Financial Performance Analysis of BIST Tourism Companies with TOPSIS for 2011-2015

Period

www.tursab.org.tr

Yavuz, N. Ç. (2006). Türkiye'de turizm gelirlerinin ekonomik büyümeye etkisinin testi: yapısal kırılma ve nedensellik analizi. Doğuş Üniversitesi Dergisi, 7(2), 162-171.

Yayar, R., \& Baykara, H. V. (2012). TOPSIS yöntemi ile katılım bankalarının etkinliği ve verimliliği üzerine bir uygulama/An implementation upon efficiency and productivity of participation banks with TOPSIS method. Business and Economics Research Journal, 3(4), 21-42.

Yılmaz, T., Kaygın, E., \& Gerekan, B. (2016) Gıda Maddeleri Sanayii Sektöründe Faaliyet Gösteren İşletmelerin Finansal Performansının TOPSIS Yöntemi İle Ölçülmesi: BİST Örneği. Akademik Sosyal Araştırmalar Dergisi, Yıl: 4, Sayı: 33, Kasım 2016, 609-623.

Yükçü, S., \& Atağan, G. (2010). TOPSIS yöntemine göre performans değerleme. Muhasebe ve Finansman Dergisi, 45, 55-66.

Zhang, H., Gu, C. L., Gu, L. W., \& Zhang, Y. (2011). The evaluation of tourism destination competitiveness by TOPSIS \& information entropy-A case in the Yangtze River Delta of China. Tourism Management, 32(2), 443-451. 